\title{
Viscoelastic Properties of Polymer Solutions at Temperatures Lower than $\Theta$ Points
}

\author{
Yoshiaki $\mathrm{T}_{\text {AKAHASHI, Masayoshi }} \mathrm{Y}_{\text {AMAGUCHI, Daisuke }} \mathrm{S}_{\text {AKAKURA, }}$ \\ and Ichiro NODA \\ Department of Synthetic Chemistry, Nagoya University, \\ Chikusa-ku, Nagoya, 464-01 Japan
}

\begin{abstract}
Zero-shear viscosity $\eta^{0}$ and steady-state compliance $J_{\mathrm{e}}$ of poly $(\alpha$-methylstyrenes) in benzyl n-butyl phthalate $\left(\Theta=46^{\circ} \mathrm{C}\right)$ and polystyrene in dioctyl phthalate $\left(\Theta=22^{\circ} \mathrm{C}\right)$ were measured at temperatures lower than the $\Theta$ points. Moreover, stress developments after onset of steady shear flow were measured and the strength of entanglement was estimated on the basis of network rupture model.

The concentration and the molecular weight dependences of $\eta^{0}$ at temperatures lower than the $\Theta$ points are almost the same as those at the $\Theta$ temperatures, but the magnitude of $\eta^{0}$ increases with decreasing temperature. This suggests that the strength of entanglement increases with decreasing solvent power.

On the other hand, $J_{\mathrm{e}}$ values at the temperatures lower than the $\Theta$ points are almost the same as those in good and $\Theta$ solvents. This result indicates that the entangled structure of polymer solution effective to $J_{\mathrm{e}}$ is almost independent of solvent power. Therefore, it is concluded that the gel-like behavior of polymer solution at temperatures lower than the $\Theta$ points is caused by the long relaxation times due to the high viscosity. Key words: polystyrenes / poly ( $\alpha$-methylstyrenes) / zero shear viscosity / steady-state compliance / strength of entanglement
\end{abstract}

\section{$\Theta$ 温度以下の高分子溶液の粘弾性}

高橋 良彰・山口昌賢・坂倉大輔・野田一 郎*

（原稿受理：1990年 5 月 14 日）

\section{1. 緒言}

高分子と溶媒の熱力学的相互作用の強さによって高分子溶液を 良溶媒系, @溶媒液, 貧溶媒系等に分けて考えることができる. 高分子溶液の粘弾性は種々の溶媒を用いて広く研究されてきた

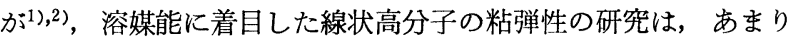
多くなされていなかった。

これまでに我々は幅広い分子量並びに濃度範囲にわたり，良溶 媒系, @溶媒系, 及びその中間の貧溶媒系について粘弾性測定を 行ってきた. その結果, 高分子溶液の粘度挙動には準希薄領域が 存在し，そこでの粘度の濃度依存性は，スケーリング則を用いれ ば溶媒能による違いも含めて理解できること，また粘度に対する 高分子鎖の絡み合い効果は，溶媒の性質が良溶媒から@溶媒に移 行するにつれて，より低い高分子鎖の重なり度合いで現われるこ と, 一方定常状態コンプライアンスの濃度依存性には, ほとんど

* 名古屋大学工学部合成化学科 $\mathbf{T} 464-01$ 名古屋市千種区
溶媒効果がないことなどを明らかにした ${ }^{3) \sim 5) . ~}$

@温度以下の高分子溶液は, 相互作用が強いため一見ゲルのよ うな状態を示し大変興味深い系であるが，比較的容易に相分離を おこし，その取り扱いが難しいため，この溶液についての研究は 希薄溶液の固有粘度測定等を除けばほとんど行われていない。そ こで本研究では, 比較的濃度の高い線状高分子溶液を用いて，® 温度以下でかつ相分離していない領域を中心に，主として線形領 域の粘弹性の測定を行い，®点以下の高分子溶液の粘弾性挙動が ぞのように理解できるかを良溶媒系並びに@溶媒系での実験結果 と比較して考察する。

\section{2. 実験}

用いた試料は，当研究室でアニオン重合法により合成された分 子量分布の狭いポリ $\alpha$-メチルスチレン， $\alpha-005$ (分子量44.4万) とポリスチレン， SM-10 (分子量37万) 扣よび東ソー社製のポリ スチレン, F-80（分子量71万）である. 溶媒はポリ $\alpha$-メチルス 
チレンにはフタル酸 n-ブチルベンジル(BBP) を, ポリスチレン にはフタル酸ジオクチル(DOP) を用いた. これらの溶媒はそれ ぞれの高分子に対する®溶媒であり, @温度は前者で $\left.46^{\circ} \mathrm{C}^{6}\right)$, 後 者で $22^{\circ} \mathrm{C}^{7)}$ である.

粘弾性測定は, レオメトリクス社製メカニカルスペクトロメー タ RMS800 を用い. 直径 $25 \mathrm{~mm}$ の平行円板系で振動モードで行

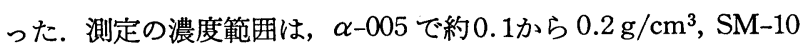

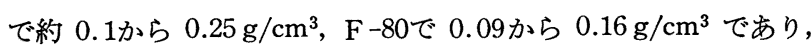
一つの試料につき 5 濃度程度測定した。 また測定の温度範囲は, ポリスチレンの系では $5 \sim 40^{\circ} \mathrm{C}$, ポリ $\alpha$-メチルスチレンの系で

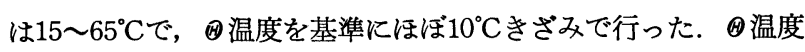
以下での測定では，@温度以上で試料溶夜を平行円板間に挿んた 後, 測定温度まで下げ, 15分程度経過後に溶液が白濁しないこと を確認してから行った。

また， $\alpha-005$ の $0.15 \mathrm{~g} / \mathrm{cm}^{3}$ 溶液については，円錐円板系を用 い, 温度を変えて定常流動開始後の応力成長を測定し, 後述の網 目崩壊モデル8)に基づいて絡み合いの破壊エネルギーを求めた.

\section{3. 結果と考察}

本実験では零ずり粘度 $\eta^{0}$ と定常状態コンプライアンス $J_{\mathrm{e}}$ は, それぞれ振動実験から得られた貯蔵弾性率 $G^{\prime}(\omega)$ と損失弾性率 $G^{\prime \prime}(\omega)$ を用いて, 次式から求めた.

$$
\begin{aligned}
& \eta^{0}=\lim _{\omega \rightarrow 0} \frac{G^{\prime \prime}(\omega)}{\omega} \\
& J_{\mathrm{e}}=\frac{1}{\eta^{02}} \lim _{\omega \rightarrow 0} \frac{G^{\prime}(\omega)}{\omega^{2}}
\end{aligned}
$$

準希薄領域で粘度にスケーリング則を適用すると, 還元零ずり 粘度 $\eta^{0}$ \&, 絡及領域の $\eta^{0}$ の分子量依存性 $\eta^{0} \propto M^{3.4}$ 之回転半 径の分子量依存性 $\left\langle S^{2}\right\rangle^{1 / 2} \propto M^{\nu}$ の指数 $\nu$ 用いて，高分子鎖の 重なり度合い $C / C^{*}$ の関数として次式で与えられる.

$$
\eta^{0}{ }_{\mathrm{R}} \equiv \eta_{\mathrm{SP}} / C[\eta] \propto\left(C / C^{*}\right)^{(4.4-3 \nu) /(3 \nu-1)}
$$

ここで, $\eta_{\mathrm{SP}}=\left(\eta^{0}-\eta_{\mathrm{S}}\right) / \eta_{\mathrm{S}}, \eta_{\mathrm{S}}$ は溶媒粘度, $C^{*}=3 M /(4 \pi$ $\left.\left\langle S^{2}\right\rangle^{3 / 2} N_{\mathrm{A}}\right), N_{\mathrm{A}}$ はアボガドロ数である.@点では $\nu=1 / 2$ なので, 式(1)から

$$
\eta^{0}{ }_{\mathrm{R}} \propto\left(C / C^{*}\right)^{5.8}
$$

あるいは,

$\eta_{\mathrm{SP}} / M^{3.4} \propto C^{6.8}$

となる ${ }^{1), 3)}$.

今回得られた粘度の結果のうち，状態での結果を従来の測定

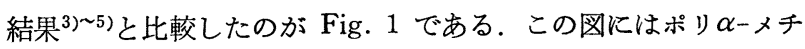
ルスチレンとポリスチレンの粘度の結果を, 式(3)に対応させて $\eta_{\mathrm{SP}} / M^{3.4}$ の濃度 $C$ に対する両対数プロットで示してある. 図中実 線は式(3)を示して括り，白抜きの記号が今回得られた值である. 若干ばらつきはあるが，®状態では両高分子試料溶液のデータに 差はなく, 従来の結果と良く一致して扣り, 実験結果がスケーリ ング則でよく説明できることを示している.

次に粘度の温度依存性を検討するために, $\eta_{\mathrm{SP}} を(T-\Theta) / \Theta に$ 対してプロットしたのが Fig. 2a, b である. Fig. 2a はポリ $\alpha-$ メチルスチレンの, Fig. 2b はポリスチレンの結果を示している. 温度が低くなるにつれて，ぞちらの罒に於ても方P はしだいに 大きくなっていくが，特にポリ $\alpha$-メチルスチレンの系では $\Theta$ 点 から $30^{\circ} \mathrm{C}$ 下がると，®点での值に比べてほぼ 2 桁高くなっている.

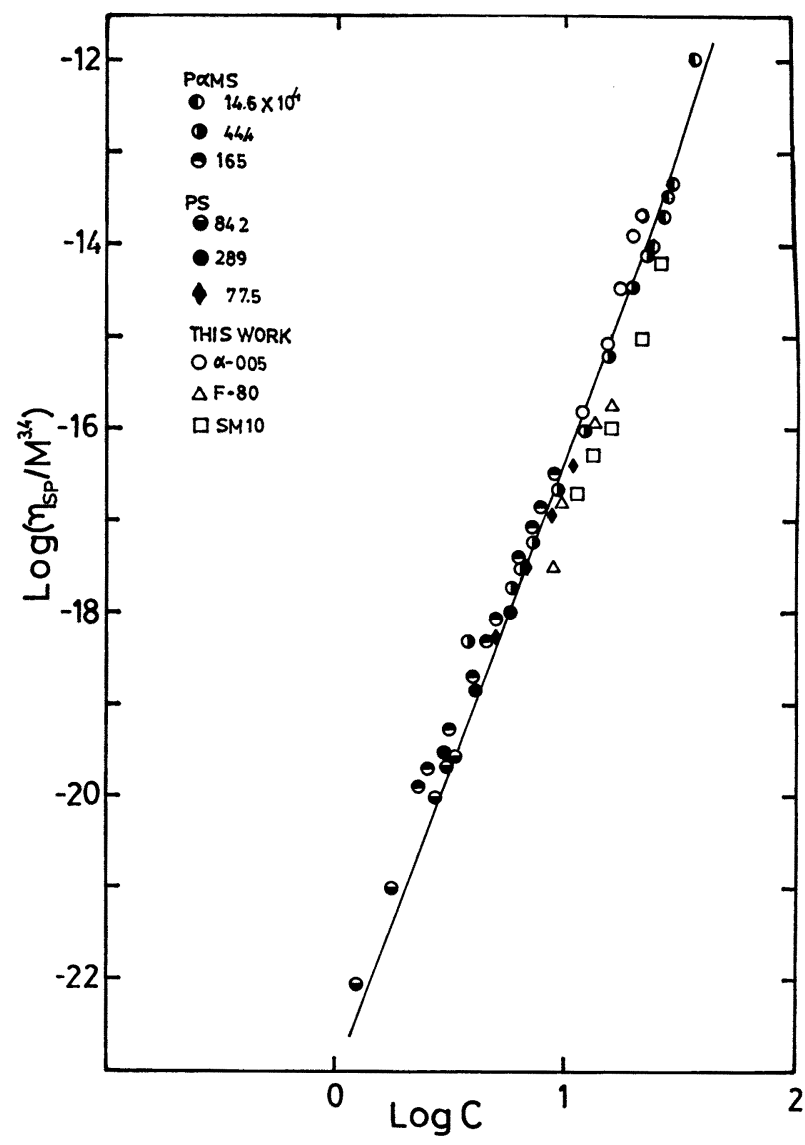

Fig. 1 Double logarithmic plots of $\eta_{\mathrm{SP}} / M^{3.4}$ vs. $C$ for polystyrenes in DOP and poly ( $\alpha$-methylstyrenes) in $\mathrm{BBP}$ at the $\Theta$ temperatures. Symbols are denoted in the figure. The solid line denotes the slope of eq. $\left.3^{3), 5}, 6\right)$.

一方, 巴点より温度が高くなると， $\eta_{\mathrm{SP}}$ の温度による変化は小さ くなってきて, ポリスチレンの系では高温側ではほとんど温度に よる差が無くなっている.

更に, 各測定温度での $\eta_{\mathrm{SP}}$ の濃度並びに分子量依存性を検討す るために, Fig. 3a にポリ $\alpha$ メチルスチレンの $\eta_{\mathrm{SP}}$ を濃度に対 して両対数プロットで示した. また, Fig. 3b にはポリスチレン のデータを分子量の 3.4 乗で割った值の, 濃度に対する両対数プ ロットを示した．戝中の黑抜きの丸は，点での值を示している. また, Fig. 3b 中の SM-10の $10^{\circ} \mathrm{C}$ に拈ける值は, Fig. $2 \mathrm{~b}$ で内挿 により求めた值である.

ポリスチレンのデータは少し荒れて和り，どちらの系に拈いて も各温度に拈けるデータの数が少ないので, それぞれの濃度依存 性を直接求めることはできないが，図中実線で示したように各温 度のデータは, @点のデータに対して平行に引いた直線で表すこ とができる。この結果から，®点以下の高分子溶液に扣いても $(\Theta-30)^{\circ} \mathrm{C}$ 程度の温度範囲では, 温度の変化々共に比粘度 $\eta_{\mathrm{SP}}$ は 著しく增大寸るが，その濃度依存性は@溶媒の系 ${ }^{3), 5)}$ と同様に式 (3)で表せると考えられる. また，ポリスチレンで検討した分子量 依存性も式(3)と矛盾していない，しかし，式(3)では先に述べた $\eta_{\mathrm{SP}}$ の温度依存性は予測されないので, 温度依存性については別 の観点での検討が必要である. 

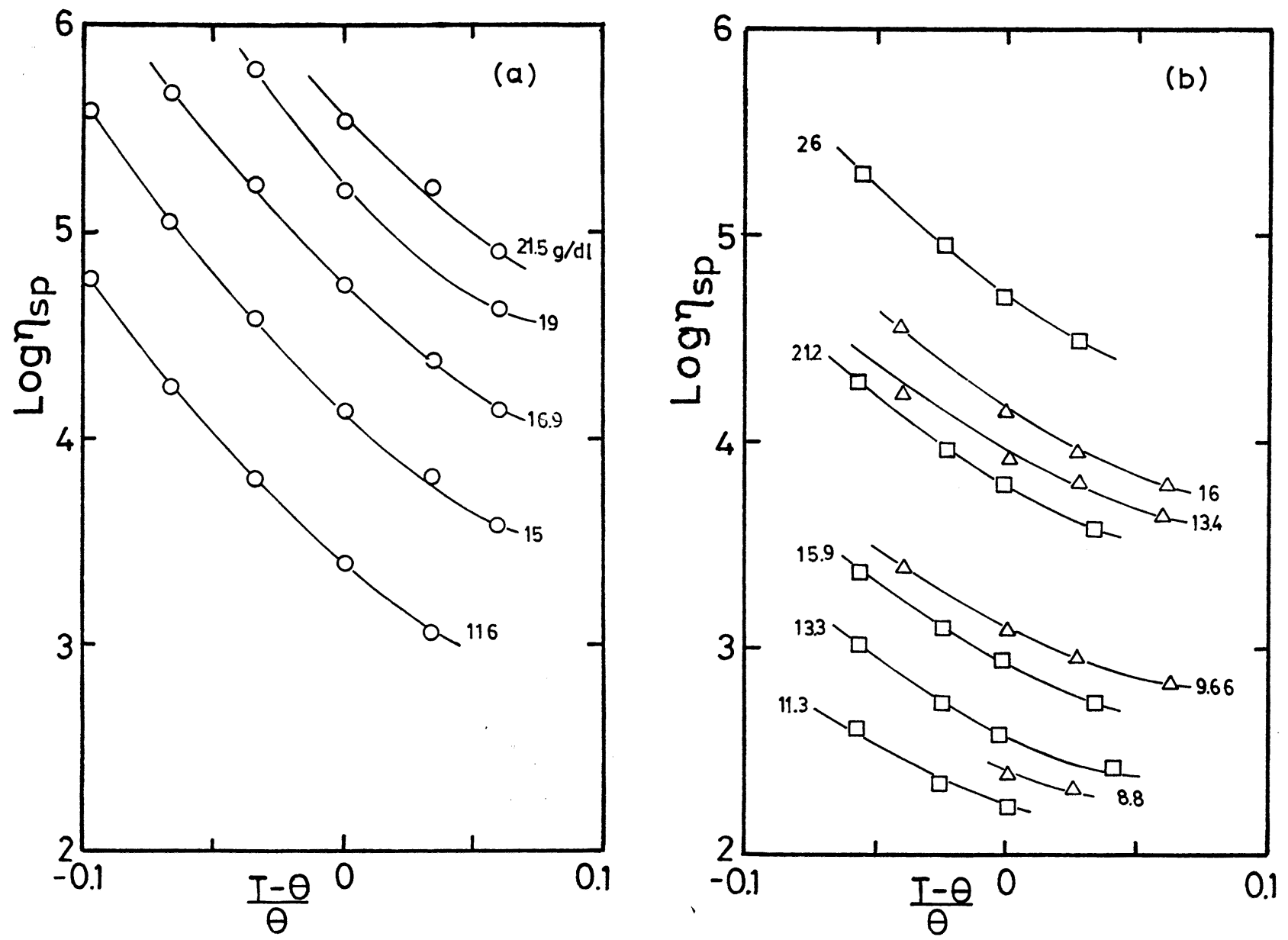

Fig. 2 Plots of $\log \eta_{\mathrm{SP}}$ vs. $(T-\Theta) / \Theta$ for poly $(\alpha$-methylstyrenes) in BBP (a) and polystyrenes in DOP (b)at various concentrations. The symbols are the same as in Fig. 1. Concentrations are denoted in the figure.
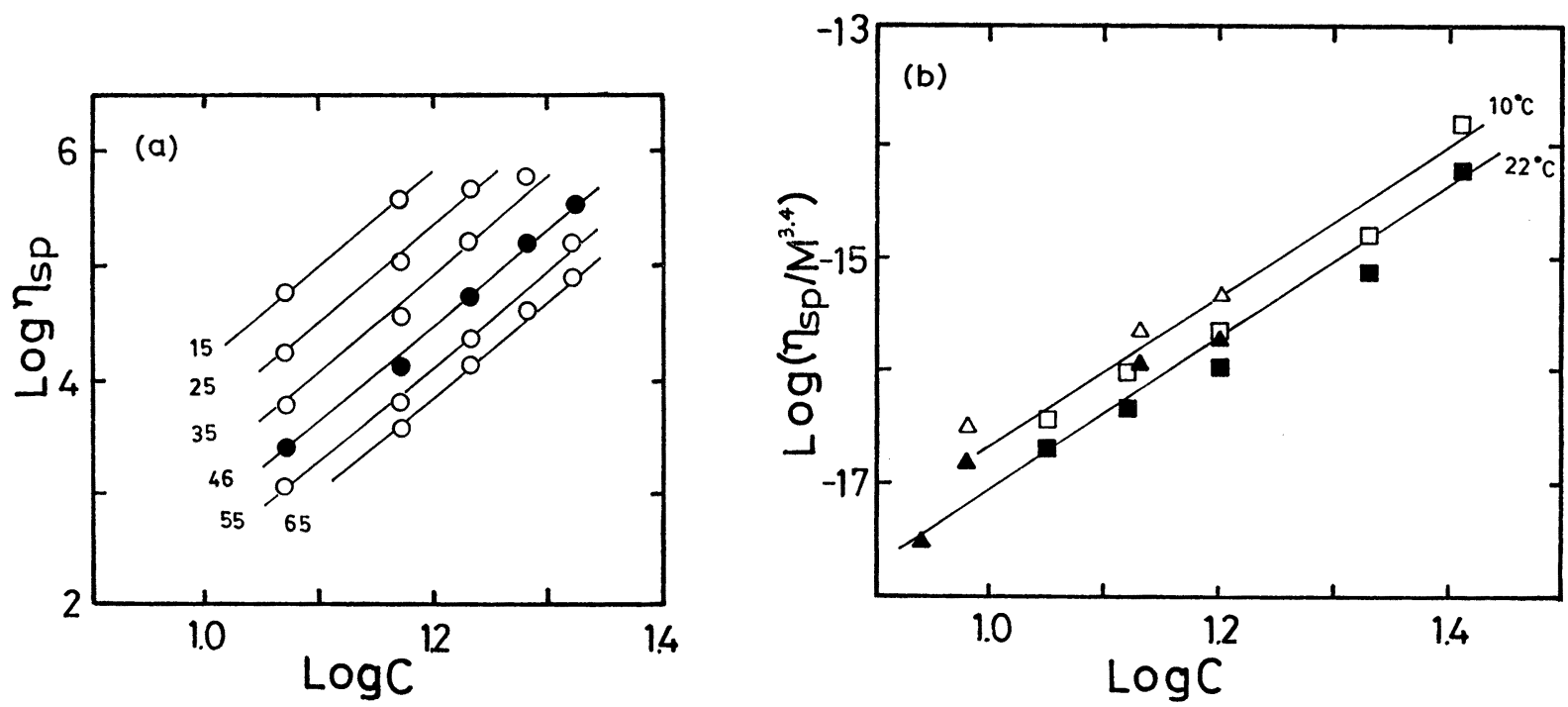

Fig. 3 Concentration dependence of $\eta_{\mathrm{SP}}$ for poly ( $\alpha$-methylstyrenes) in BBP (a) and polystyrenes in DOP (b) at various temperatures. The symbols are the same as in Fig. 1 and the filled ones show the data at the $\Theta$ temperature. Temperatures are denoted in the figure. 
そこで $25,35,46(\circledast)^{\circ} \mathrm{C}$ 三つの温度で, $\alpha-005$ の $0.15 \mathrm{~g} / \mathrm{cm}^{3}$ 溶液の定常流動開始後の応力成長測定を行い, 絡みの強さの温度

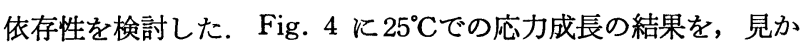
けの粘度 $\eta^{\mathrm{d}}(t \mid \dot{\gamma})=P_{21}(t \mid \dot{\gamma}) / \dot{\gamma}$ 対時間 $t$ の形で示してある. ここ で, $P_{21}(t \mid \dot{\gamma})$ はずり応力, $\dot{\gamma}$ はずり速度である. この図から明ら かなようにの点以下でも，見かけの粘度は流動初期ではずり速度 によらず一本の曲線になり，時間の経過とともに各ずり速度に対 応する定常值に達するが，その值はずり速度の增加とともに減少 している，また，ずり速度が高い場合にはオーバーシュートを示 しており，よく知られている典型的な応力成長の結果と定性的に 一致している(1),2),6),7)。他の温度に执いても同様な結果が得られ た.

このような応力成長曲線の特徴は, 次のように理解することが できる. すなわち, 高分子物質は絡及点密度で表される内部構造 を持ち，その構造が粘弾性挙動を支配していて，粘度のずり速度 依存性は有効絡み合い密度が減少することにより起きる. しかし， そのような構造変化は流動開始後瞬時に起きるのではなく，ある 時間的遅れを伴って起きるので, 流動初期では見かけの粘度はず り速度によらず一本の曲線になり，ある臨界歪みを超えると絡み 点が破壊され, その構造変化に対応して定常状態の值に近づいて いくと考えられる．梶浦らは8)このような考え方に基づいて網目 崩壊モデルを提案し, 平衡状態と定常状態の二つの内部状態間の 転移を記述する転移関数を含む形の構成方程式を提出した。この 構成方程式を用いれば, 絡及合い網目構造が平衡状態から定常流 動状態に移行するのに要する仕事量 $\Delta W$ が,

$$
\Delta W=r^{2}\left\{\int_{0}^{t_{\mathrm{s}}} \eta^{\mathrm{d}}(t \mid \dot{\gamma}) \mathrm{d} t-t_{\mathrm{s}} \eta\left(t_{\mathrm{s}} \mid \dot{\gamma}\right)+0.5 \Psi_{12}\left(t_{\mathrm{s}} \mid \dot{\gamma}\right)\right\}
$$

で計算できる．ここで， $t_{\mathrm{s}}$ は定常状態に達した後のある時刻であ $\eta, \eta\left(t_{\mathrm{s}} \mid \dot{\gamma}\right)$ と $\Psi_{12}\left(t_{\mathrm{s}} \mid \dot{\gamma}\right)$ はそれぞれ定常ずり粘度と定常第一法線 応力差係数である. この方法により五十野ら ${ }^{6)}$ は, 良溶媒中より も因溶媒中で絡み合いの破壊エネルギーが大きい。すなわち，絡 み合いが強いことを報告している、この結果は, 前述の®溶媒中 の方が良溶媒中に比べて低い重なり度合いで, 粘度が絡み合い領

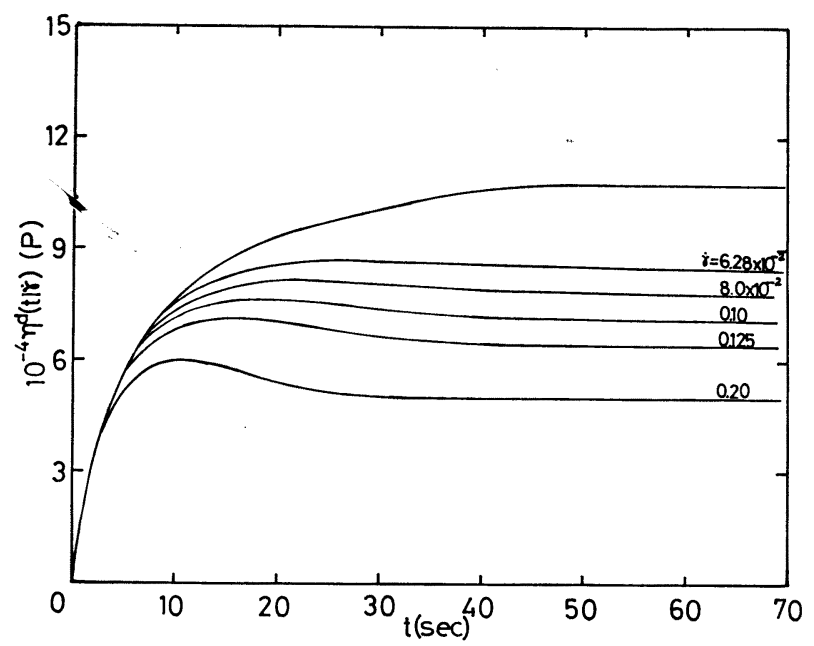

Fig. 4 Experimental transient viscosity $\eta^{\mathrm{d}}(t \mid \dot{\gamma})$ after the onset of steady shearflow for $0.15 \mathrm{~g} / \mathrm{cm}^{3}$ solution of $\alpha-005$ at $25^{\circ} \mathrm{C}$. The shear rates are denoted in the figure and the uppermost curve shows the data in linear viscoelastic region.
域に入ることと対応している ${ }^{3)}$.

@点以下の高分子溶液について絡み合いの強さを評価するため に, $\alpha-005$ の $0.15 \mathrm{~g} / \mathrm{cm}^{3}$ 溶夜の応力成長の結果に式(4)を適用し た. 得られた $\Delta W$ の值を Fig. 5 に示した. ここで得られた值 は, $\eta(\dot{\gamma}) / \eta^{0}=0.67$ の場合の結果である．装置の測定限界などの ために，ここに示した以外のデータは得られなかったが，すでに 五十野ら ${ }^{6)}$ の研究により $\Delta W / C^{2}$ が分子量及び濃度によらず，破 壊された絡み点の数だけに依存することが明らかにされているの で, 温度変化にともなう絡み点の破壊エネルギーの変化を見るに はこれで充分であろう．Fig. 5 に示したように，温度の低下とと もに絡み合いの破壊エネルギーが大きくなっているのは明らかで ある.

一方, 絡及領域の定常状態コンプライアンス $J_{\mathrm{e}}$ は, 弾性率の逆 数に比例すると考えられるので，スケーリング則が成り立てば還 元定常状態コンプライアンス $J_{\mathrm{eR}}=\left(J_{\mathrm{e}} C R T / M\right) \cdot\left\{\eta^{0} /\left(\eta^{0}-\eta_{\mathrm{S}}\right)\right\}^{2}$ は,

$$
J_{\mathrm{eR}} \propto\left(C / C^{*}\right)^{1 /(1-3 \nu)}
$$

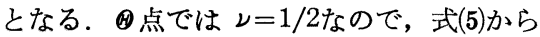

$$
J_{\mathrm{eR}} \propto\left(C / C^{*}\right)^{-2}
$$

あるいは,

$$
J_{\mathrm{e}} \propto C^{-3}
$$

となる. しかし, これまでのの溶媒中の実験結果は, 式(7)に一致 せず, ポリ $\alpha$-メチルスチレンで $J_{\mathrm{e}} \propto C^{-2}$, ポリスチレンで $J_{\mathrm{e}} \propto C^{-2.3}$ 程度になり，良溶媒系ともほとんど差はなく，均一網目モデルの 予測に近い3) 5). Fig. 6a, b にはそれぞれポリ $\alpha$-メチルスチレ

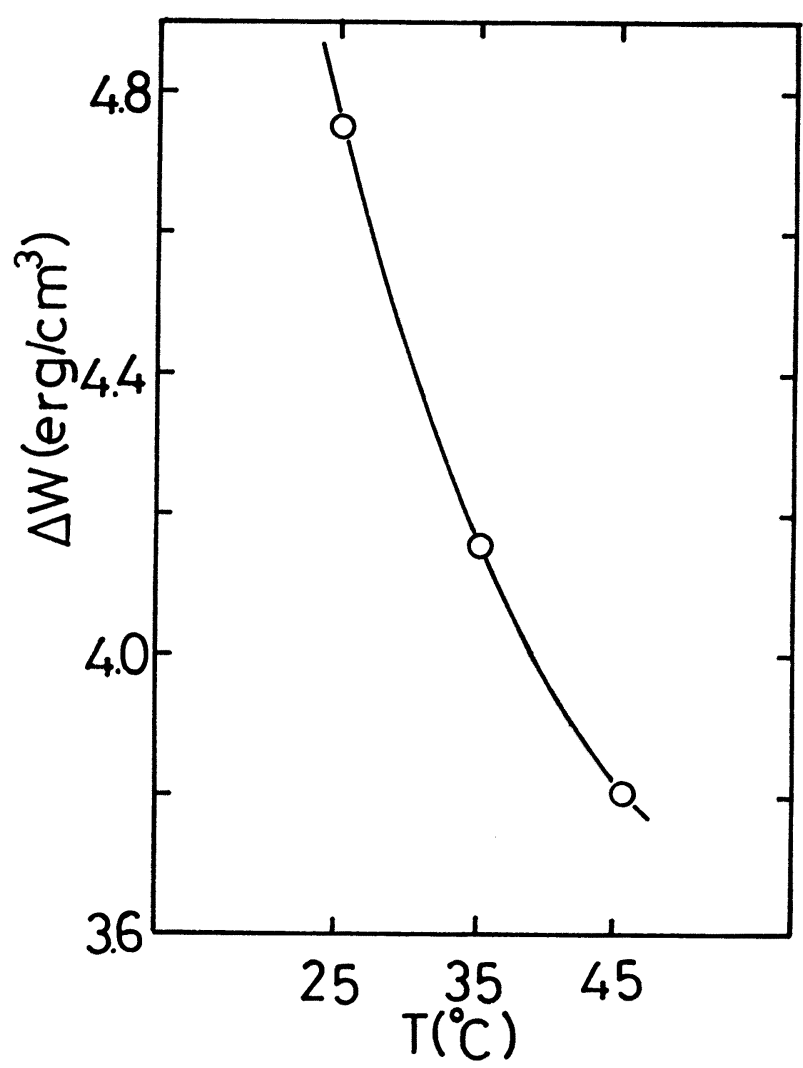

Fig. 5 Temperature dependence of the work of network rupture $\Delta W$ for $0.15 \mathrm{~g} / \mathrm{cm}^{3}$ solution of $\alpha-005$ at the rate of shear $(\dot{\gamma})$ where $\eta^{0} / \eta(\dot{\gamma})=0.67$. 

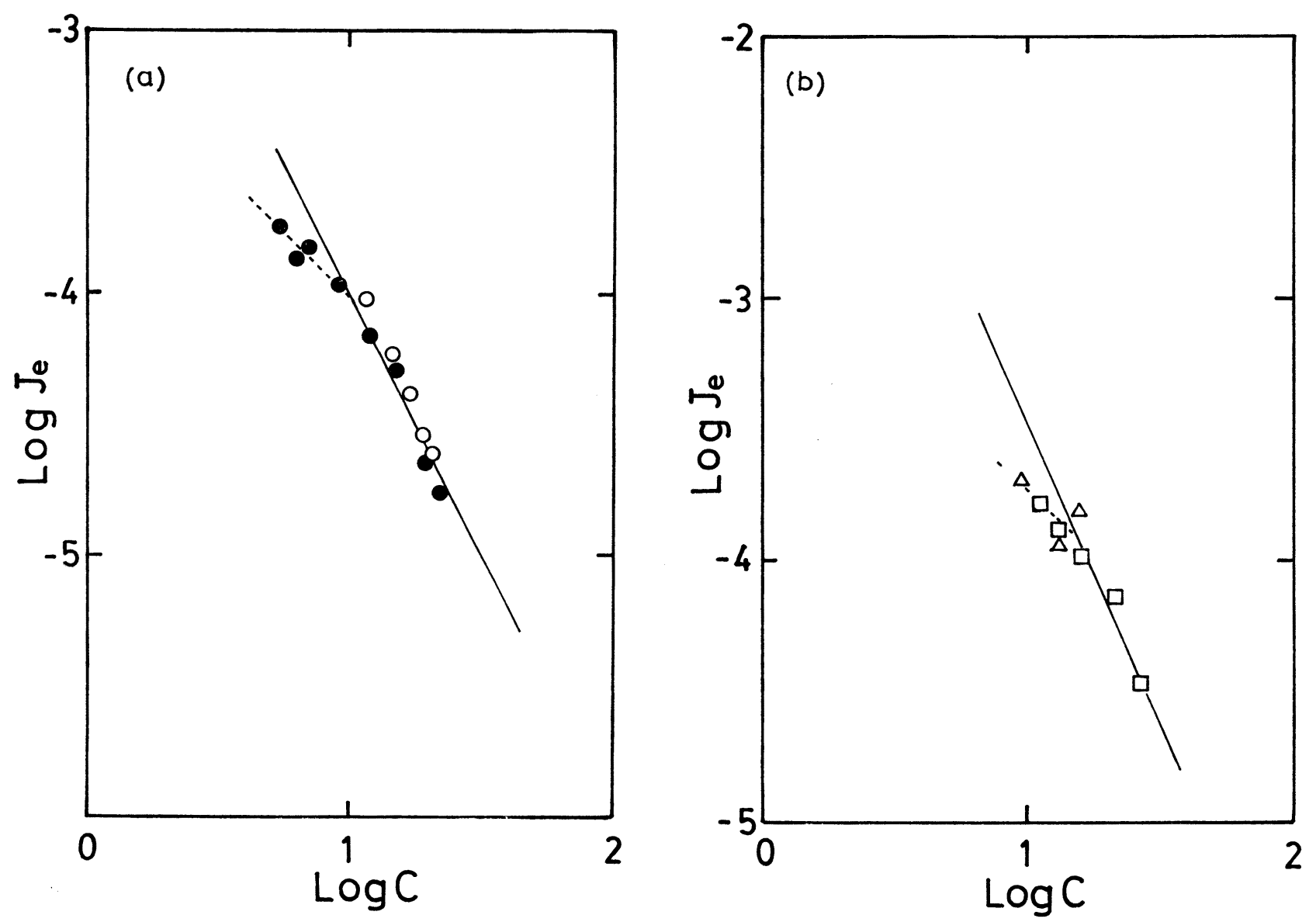

Fig. 6 Double logarithmic plots of $J_{\mathrm{e}}$ vs. $C$ for poly ( $\alpha$-methylstyrenes) (a) and polystyrenes (b) inthe $\otimes$ solvents. The solid lines denote the data reported in previous papers ${ }^{3 \sim 6)}$ and filled circles show the data $\alpha-005$ in $\mathrm{BBP}$ at $50^{\circ} \mathrm{C}$. The other symbols are the same as in Fig. 1.

ンとポリスチレンの $J_{\mathrm{e}}$ の結果が， $C$ 亿対する両対数プロットで示 してある. 図中実線はそれぞれの試料の@状態の絡み域のデータ 3) 5)である.ささらに，比較のために@点より若干高い $50^{\circ} \mathrm{C} に$ 特け る $\alpha-005$ の BBP 溶液のデータ6)を黒丸で示した. 図から明らか なよ $5 に, J_{\mathrm{e}}$ の場合にも従来のデータとよく一致している.

次に, 定常状態コンプライアンス $J_{\mathrm{e}}$ の温度依存性を検討するた めに, $J_{\mathrm{e}}$ を $(T-\Theta) / \Theta$ に対してプロットしたのが Fig. 7 であ る. 因中のデータはそれぞれの@点を基準として, $\left(T \rho / \Theta \rho^{0}\right)$ を 乗じて補正してあるが，この補正によるデータの変動はほとんど 無視できる程度であった. SM-10 と F-80の低濃度でのデータは, 丹点以下で若干温度の減少とともに增加しているが，その変化は Fig. 2 に示した粘度の場合に比べればはるかに小さく, 他のデ ータは温度によらずほぼ一定である.この結果と Fig. 6 の結果 を併せて考えれば, 今回の@点以下の高分子溶液の $J_{\mathrm{e}}$ の值は, 以前に報告した良溶媒並びに@溶媒系のデーダ 3) ともほぼ一致 しており，J值は溶媒能にほとんど依存しないと考元られる。

以上の結果から次の結論が得られる. ®点以下の高分子溶液の 零ずり粘度の分子量並びに濃度依存性は, @溶媒中とほぼ同じで あるが，その大きさは温度の減少とともに増加する．これは絡み 合いの強さが, 溶媒能が低下するほど増大するためと考えられる.
一方, 定常状態コンプライアンスは®点以下に打いても良溶媒, 巴溶媒系とほとんど変わらず, このことは溶液中の有効な絡み合 い構造が溶媒能によってほとんど変化しないことを意味している. 従って, ®点以下の高分子溶液がゲル状に見えるのは, 弾性項が 変化するのではなく, 絡みの強さの増大による粘性項の增大に上 り，系の緩和時間が非常に長くなるためであると考えられる. Fig. 8 に, $\eta^{0}$ と $J_{\mathrm{e}}$ の積で定義される重量平均緩和時間 $\tau_{\mathrm{w}}$ の温 度依存性を示した. 図中点線は溶媒粘度の温度依存性を示してい る. 図から明らかなように, 低温側では $\tau_{\mathrm{w}}$ は著しく增大してお り，この結果は上述の結論を支持している（1989年10月18日， 第37回レオロジー討論会 (九州) にて発表)

本研究の一部は平成元年度科学研究費補助金 (Na63430019) に よって行われた. 


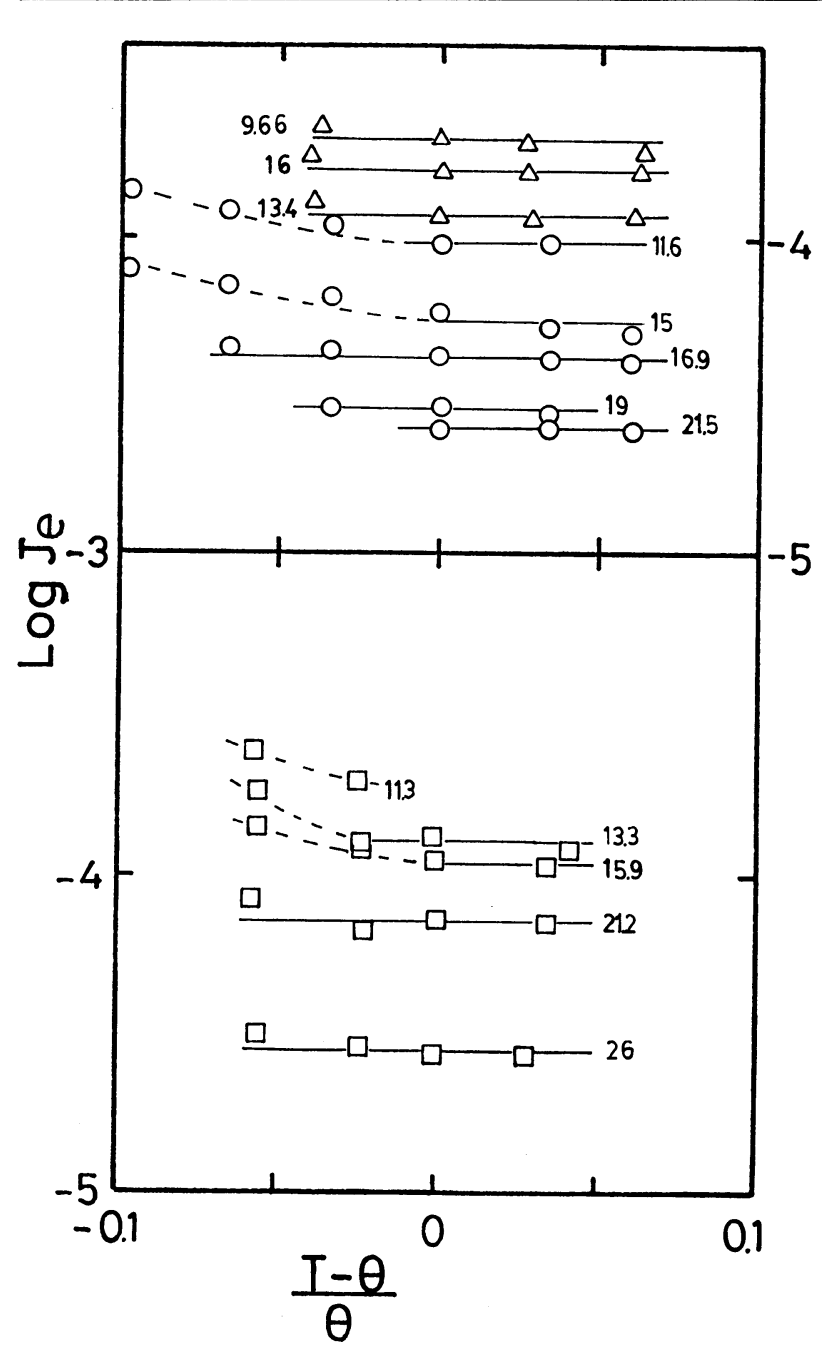

Fig. 7 Plots of $\log J_{\mathrm{e}}$ vs. $(T-\Theta) / \Theta$ for poly $(\alpha$-methylstyrenes) in BBP and polystyrenes in DOP at various concentrations. The symbols are the same as in Fig. 1. Concentrations are denoted in the figure.

\section{文献}

1) Graessley, W. W., Adv. Polym. Sci., 16, 1 (1974).

2) Ferry, J. D., "Viscoelastic Properties of Polymers", 3rd ed. (1980), Wiley, NY, Chap. 17.

3) Takahashi, Y., Y. Isono, I. Noda, and M. Nagasawa, Macromolecules, 18, 1002 (1985).

4) Takahashi, Y., I. Noda, and M. Nagasawa, Macromolecules, 18, 2220 (1985).

5) Takahashi, Y., M. Umeda, and I. Noda, Macromole. cules, 21, 2257 (1988).

6) Isono, Y., and M. Nagasawa, Macromolecules, 13, 862 (1980).

7) Isono, Y., T. Fujimoto, H. Kajiura, and M. Nagasawa, Polym. J. (Tokyo), 12, 363 (1980).

8) Kajiura, H., M. Sakai, and M. Nagasawe, Trans. Soc. Rheol., 20, 575 (1976).
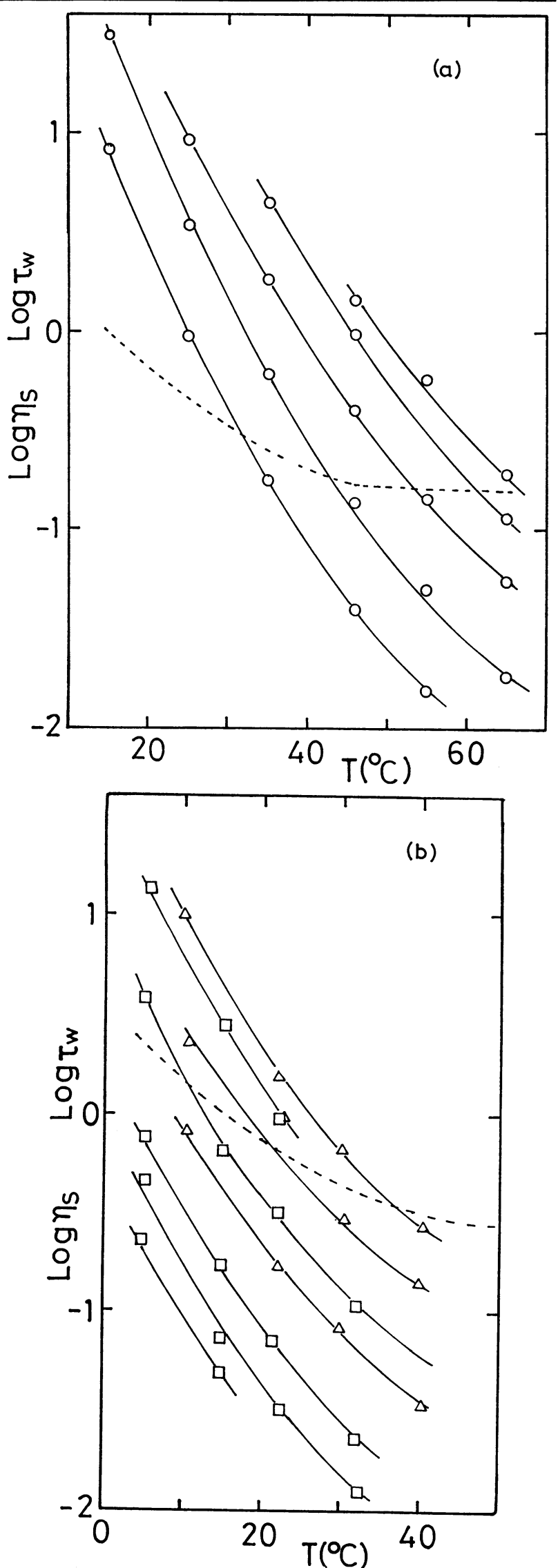

Fig. 8 Plots of $\log \tau_{\mathrm{w}}$ vs. $T$ for poly $(\alpha$-methylstyrenes $)$ in BBP (a) and polystyrenes in DOP (b). The symbols are the same as in Fig. 1. Dotted line denote the temperature dependence of solvent viscosity. 